\title{
The use of dialysis bath fluid as a vehicle for a drug with a narrow therapeutic index-lithium chloride
}

\author{
W. F. OAKLEY \\ M.B., M.R.C.P., M.R.C.PsY. \\ Maudsley Hospital
}

\author{
W. F. Clarke \\ M.D.
}

King's College Hospital

\author{
V. PARSONS \\ D.M., F.R.C.P. \\ King's College Hospital
}

\begin{abstract}
Summary
A patient requiring regular haemodialysis treatment (RDT) for end stage chronic pyelonephritis, with a recurrent manic-depressive illness was successfully treated with lithium chloride by adding it to the dialysate, when other routes had failed.

\section{Case history}

The patient was a 47-year-old housewife who began RDT in March 1972, at which time she was oedematous, her blood urea was $250 \mathrm{mg} / 100 \mathrm{ml}$, her
\end{abstract}

creatinine $22 \mathrm{mg} / 100 \mathrm{ml}$ and her haemoglobin $5.9 \mathrm{~g} \%$. Six weeks after the onset of RDT when the patient's physical condition had improved and her predialysis blood urea was $170 \mathrm{mg} / 100 \mathrm{ml}$ and her creatinine $14.5 \mathrm{mg} / 100 \mathrm{ml}$, she became hypomanic. Four years before RDT the patient had a documented episode of hypomania and a long personal and family history of psychiatric illness. At the time of initiation of haemodialysis the patient had appeared entirely well adjusted, having been employed in a trusted government post until a month before.

TABLE 1. Plasma lithium values (mEq/l) on consecutive dialysis days

\begin{tabular}{|c|c|c|}
\hline Pre-dialysis & Post-dialysis & Comment \\
\hline \multicolumn{3}{|c|}{ Oral lithium $10-20 \mathrm{mEq}$ daily } \\
\hline $1 \cdot 4$ & 0.4 & \multirow[t]{2}{*}{ On fourth day of lithium therapy. } \\
\hline $0 \cdot 5$ & $0.4)$ & \\
\hline $0 \cdot 2$ & $0 \cdot 4\}$ & \multirow[t]{3}{*}{ Vomiting caused very variable absorption. } \\
\hline $0 \cdot \overline{8}$ & $0 \cdot 3$ & \\
\hline $1 \cdot 3$ & $0 \cdot 5$ & \\
\hline $1 \cdot 3$ & $0.9\}$ & \multirow[t]{2}{*}{ Levels fluctuated wildly after $9 \mathrm{hr}$ dialysis. } \\
\hline $1 \cdot 8$ & $1 \cdot 0$ & \\
\hline $1 \cdot 0$ & $0 \cdot 5$ & Oral lithium discontinued owing to toxicity. \\
\hline \multicolumn{3}{|c|}{ Dialysate lithium $0.9-1.0 \mathrm{mEq} / \mathrm{l}$} \\
\hline & 0.3 & \multirow{5}{*}{$\begin{array}{l}\text { Three days and } 2 \text { dialyses after last lithium orally. } \\
\text { First dialysis with lithium. } \\
\text { Second dialysis with lithium. } \\
\text { Third dialysis next day. }\end{array}$} \\
\hline $0 \cdot 4$ & 0.7 & \\
\hline $0 \cdot 6$ & 0.9 & \\
\hline $0 \cdot 7$ & $0 \cdot 8$ & \\
\hline $0 \cdot 7$ & 0.6 & \\
\hline $0 \cdot 8$ & $0 \cdot 8)$ & \multirow{3}{*}{ Moderate myoclonic twitching present. } \\
\hline 0.8 & $0.9\}$ & \\
\hline $0 \cdot 7$ & $0.7 \mathrm{j}$ & \\
\hline \multicolumn{3}{|c|}{ Dialysate lithium $0.7-0.8 \mathrm{mEq} / 1$} \\
\hline 0.7 & & \multirow[t]{5}{*}{ Myoclonic twitching less, but present. } \\
\hline $0 \cdot 8$ & & \\
\hline $0 \cdot 7$ & & \\
\hline $0 \cdot 6$ & & \\
\hline $0 \cdot 8$ & & \\
\hline
\end{tabular}


In her hypomanic phase the patient discontinued her low sodium and potassium diet requiring hospital admissions for therapy, and while on dialysis she would clamp and disconnect her arterio-venous shunt at will. The patient had also refused oral medications and thus a 1-month course of intramuscular phenothiazines was commenced. When this had failed the patient was started on a course of oral lithium (Coppen et al., 1971; Prien, 1971), but variability in the levels of lithium due to vomiting, and the constant need for supervision to ensure the medication was taken, posed serious problems. Following haemodialysis the patient's lithium level would fluctuate from a toxic range (Schou, Amidsen and Trap-Jensen, 1968) to subtherapeutic levels (Table 1).

Owing to this variability in blood levels and the narrow therapeutic range (Amidsen and Skjoldberg, 1968) of lithium chloride, it was decided to add it to her dialysate solution. The dialysis bath contained lithium chloride of a concentration of $1 \mathrm{mEq} / \mathrm{l}$ and this rapidly produced a plasma level of lithium between 0.8 and $0.9 \mathrm{mEq} / 1$ which was constant before and after dialysis (Table 1).
Although a hypomanic episode is a rare occurrence, being reported once previously (Cooper, 1967), this method of approach successfully controlled the patient's symptoms and may prove useful for other dialysable drugs which exhibit a narrow therapeutic range.

\section{Acknowledgments}

We are grateful to the nursing staff of the renal unit, and particularly to Sister Mary Rolt, for their continued care of this challenging patient.

\section{References}

Amidsen, A. \& SkJoldberg, H. (1968) Haemodialysis for lithium poisoning. Lancet, ii, 23.

COOPER, A.J. (1967) Hypomanic episode precipitated by haemodialysis. Comprehensive Psychiatry, 8 (3), 168.

Coppen, A., Noguera, R., Bailey, J., Burns, B.H., Swami, M.S., Hare, E.H., Gardner, R. \& Maggs, R. (1971) Prophylactic lithium in affective disorders. Lancet, ii, 274.

PriEN, R.F. (1971) Lithium carbonate: a survey of the history and current status of lithium in the treatment of mood disorders. Diseases of the Nervous System, 32, 521.

Schou, M., Amidsen, A. \& Trap-Jensen, J. (1968) Lithium poisoning. American Journal of Psychiatry, 125, 520. 


\section{Books received}

Psychogeriatrics. An introduction to the psychiatry of old age. By Brice Pitr. Pp. vii +183 , soft cover. Edinburgh: Churchill Livingstone. $£ 2.25$.

Abdominal Echography. Ultrasound in the diagnosis of abdominal conditions. By Ellis BarNetT and PATRICIA MORLEY. Pp. $x+138$, illustrated, soft cover. London: Butterworth's. $£ 4.50$.
Guide to Psychiatry. By Myre SIM. Third edition, pp. xi + 1223, hard cover. Edinburgh: Churchill Livingstone. $£ 6.00$.

The Epilepsies. Modern diagnosis and treatment. By J. M. Sutherland, H. Tait and M. J. Eadie. Second edition, 149 pp., soft cover. Edinburgh: Churchill Livingstone. $£ 2.50$.

\section{Book review}

\author{
Larrey: Surgeon to Napoleon's Imperial Guard \\ By Rober' G. Richardson. Pp. viii +266 , illustrated. \\ London: John Murray, 1974. £4.50.
}

The author is to be congratulated for finding as his subject a man of whorn it has been said that he holds a place in history as the greatest, the bravest, the most dedicated and the most indefatigable surgeon who ever existed and, certainly for his time, the most brilliant and by far the most advanced in theory and practice. And what a practice, when one considers that be was present at virtually every single battle under Napoleon's personal command, from the first Italian Campaign to Waterloo. He was indeed present at many more battles than any of the twenty-six Marshals of France. Larrey can also rightfully be said to have awakened the conscience of mankind to the inhumanity of war. Before him, casualties had simply been a nuisance on the battlefield. As early as the battle of Valmy in 1792 (his first campaign), inspired by watching the flying Horse Artillery going into action, he invented the flying ambulance which he frequently took into the thick of the fighting, often amputating, and dressing wounds under fire, ignoring rank and treating the severely wounded first, whether friend or foe.

Dr Richardson's portrait is based largely on Larrey's own letters, journals and notes, including the unpublished collection in the Wellcome Institute. The biography is by a doctor about a surgeon (who, as the book reveals, was also a great physician). It is, therefore, based on medical sources and the theme is essentially medical throughout. But the author must be additionally complimented for his skilful weaving of the medical with the military, political and human aspects of that fabulous and terrible drama known as the Napoleonic Wars. As indicated above, the author deserves the highest praise for a well compiled and beautifully written story to which are added maps and many interesting illustrations. It is likely to appeal equally to doctors, soldiers, historians or any serious reader, who will find that this is the kind of book which it is desperately difficult to close before the last page has been read.

\section{Erratum}

Postgraduate Medical Journal, August 1974. The authors of the article 'The use of dialysis bath fluid as a vehicle for a drug with a narrow therapeutic index-lithium chloride' should have been given as H. F. Oakeley, M.B., M.R.C.P.,
M.R.C.Psych., W. F. Clarke, M.D. and V. Parsons, D.M., F.R.C.P. and not W. F. Oakley, etc. We apologise for any inconvenience caused. 